DOI: $10.2478 / s j d v-2020-0019$

\title{
Blistering Beetle Dermatitis Mimicking Herpes Zoster Oph- thalmicus: a Case Report
}

\author{
Pankaj DAS ${ }^{1}$, Sandeep ARORA¹, Gautam Kumar SINGH ${ }^{1}$, Amit BAHUGUNA¹, Neelam \\ SINGH ${ }^{1}$, Prashant BELLAD ${ }^{1}$, Aakansha GUPTA ${ }^{1}$ \\ ${ }^{1}$ Department of Dermatology, Base Hospital Delhi Cantt \& Army College of Medical Sciences, New Delhi, India
}

Correspondence: Pankaj Das, E-mail: pankaj3609@gmail.com

UDC 616.5-002.1-02:597.76]-08

\begin{abstract}
Blistering beetle dermatitis is an important dermatological disease of tropical countries. Although the clinical features are classical, little awareness amongst medical practitioners may cause difficulties in the diagnosis of this condition. Further, it may sometimes mimic an unrelated disease which can lead to delay in treatment causing prolonged suffering of the patient. We present a case of blistering beetle dermatitis that was initially misdiagnosed as a case of herpeszoster ophthalmicus. The case is presented to reinforce awareness on this dermatologicaldisease and discuss its atypical presentation and its management.
\end{abstract}

Key words: Insect Bites and Stings; Dermatitis, Contact; Coleoptera; Blister; Herpes Zoster Ophthalmicus; Diagnosis; Diagnostic Errors

\section{Introduction}

Blistering beetle dermatitis is a type of contact dermatitis caused by vesicants such as pederin and cantharidin possessed by beetles in the order Coleoptera (1). This disease is seen in most regions of the world but is prevalent in tropical countries (2). Pederin/cantharidin is released on inadvertent crushing of beetle on the skin which is responsible for causing irritant contact dermatitis which usually manifests with characteristic linearly arranged vesicles/bullae (3). Prompt irrigation of the affected part to wash off the toxin and application of topical steroids reduces the inflammation.

\section{Case Report}

A 26 years old male presented to dermatology outpatient department with history of painful fluid filled lesions around the right eye of 02 days duration. He was apparently asymptomatic before 02 days when on waking up, he complained of burning sensation associated with redness over the area around his right eye. In the next few hours, he noticed eruption of some fluid-filled lesions over the same area associated with pain. He consulted a general practitioner who diagnosed him as a case of herpes zoster ophthalmicus and started on tab acyclovir $800 \mathrm{mg}$ five times daily but the lesions continued to progress. On second visit to the general practitioner, he was referred to dermatology outpatient department. On detailed history taking, he revealed that while asleep, he felt some insect crawling over his left forearm and tried to remove it with his right hand. He noticed burning sensation and redness followed by eruption of fluid-filled lesions around his right eye, the next morning. Dermatological examination revealed a bulla, numerous tiny vesicles and crusts over erythematous and edematous upper and lower eyelids and the area around medial canthus of the right eye (Figure 1). Unaided ophthalmological examination revealed uninvolved cornea and conjunctiva with negative Hutchinson's sign (ophthalmic zoster with nasal tip involvement). There was no photophobia and vision in both eyes were 6/6. Examination of other body sites revealed involvement of right cubital fossa in form of $02 x$ erythematous crusted lesions suggestive of "kissing lesions" classically described in Blistering Beetle Dermatitis (Figure 2). The patient was counseled about the etiology and course of the blistering beetle dermatitis and managed with twice daily normal sa- 


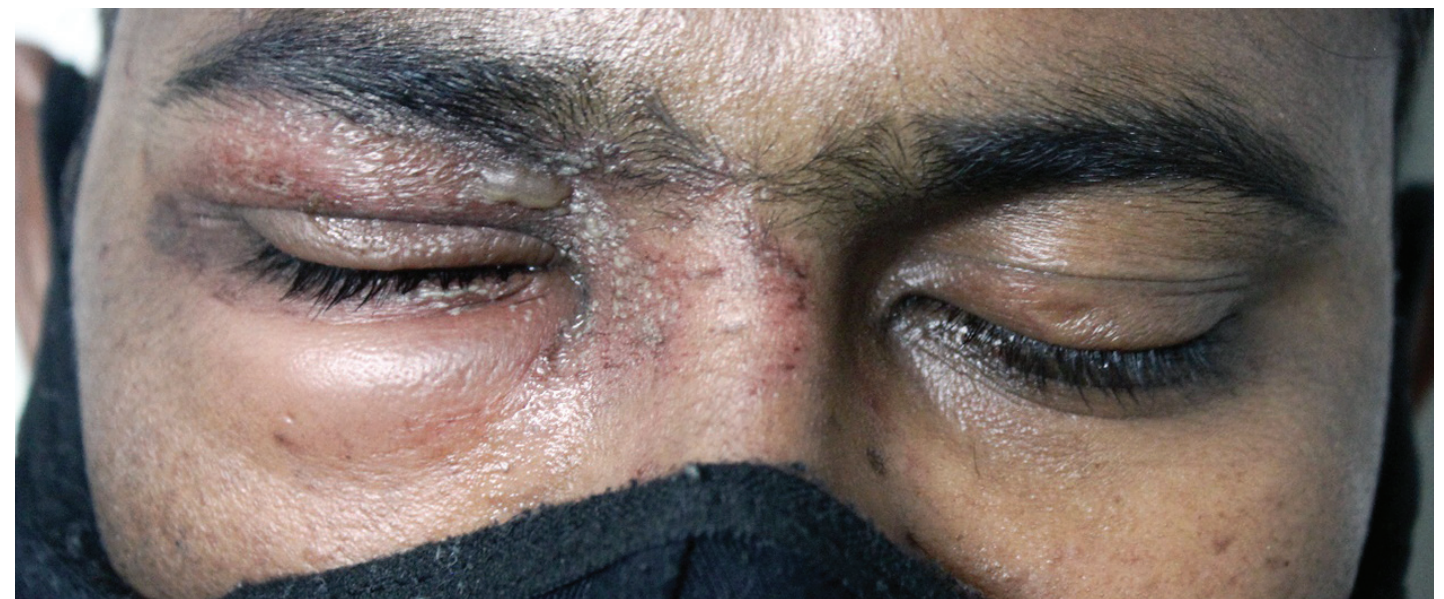

Figure 1. Numerous tiny vesicles, a solitary bulla and crusts over erythematous and edematous upper and lower eyelids and area around medial canthus of the right eye

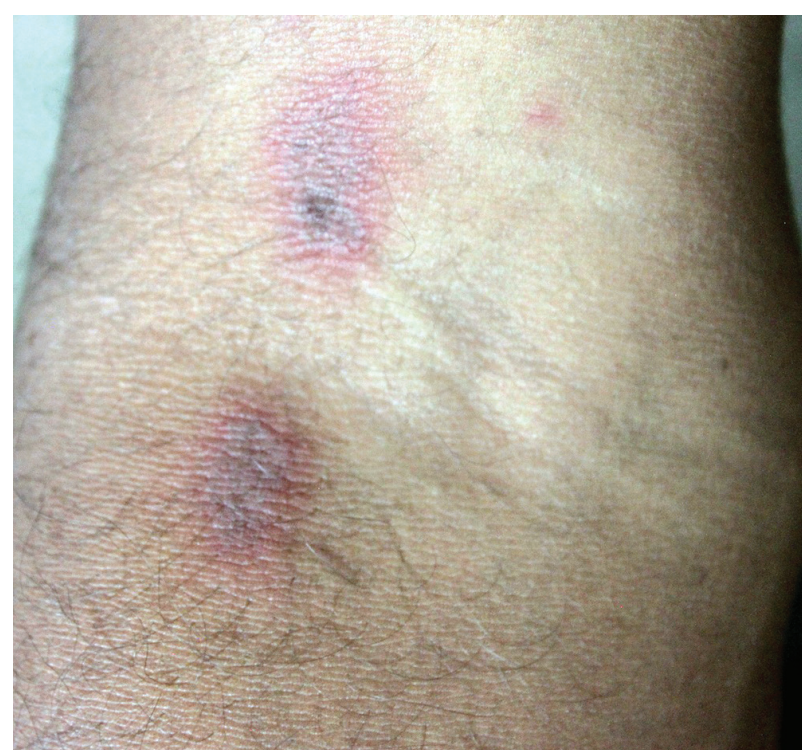

Figure 2. $02 x$ erythematous crusted lesions on the right cubital fossa suggestive of "kissing lesions" described in blistering beetle dermatitis

line compresses followed by application of mild topical steroid cream without any topical/oral antibiotics, after which the lesions resolved with hyperpigmentation in a week.

\section{Discussion}

Blistering beetle dermatitis was first described in medical literature in 1901 (4). It typically manifests as painful erythemato-vesicular rash due to a vesicant (5). Beetles causing this dermatitis belong to 03 families- Meloidae, Oedemereidae\&Staphylinidae under the order
Coleoptera (6). While cantharidin is the vesicant present in Meloidae and Oedemereidae; pederin is the chemical responsible for vesiculation in the family Staphylinidae (Rove beetles) and the genus Paederus. Differences between experimentally induced skin lesions by cantharidin and pederin are mentioned in Table 1 (7). The beetles belonging to the genus Paederus have a slender body-about 7-10 millimeter long and 0.5 millimeter wide with small elytra under which lengthy folded membranous wings are attached (8). The head and posterior one-third of the abdomen are commonly black, the thorax and anterior two-thirds of abdomen are orange or yellow, while the elytra are metallic green or blue, but may differ from species to species (Figure 3) (8). Paederus beetles prefer moist and shady habitat like soil cracks, rock crevices, decaying vegetable matter, logs and barks as their larval stages

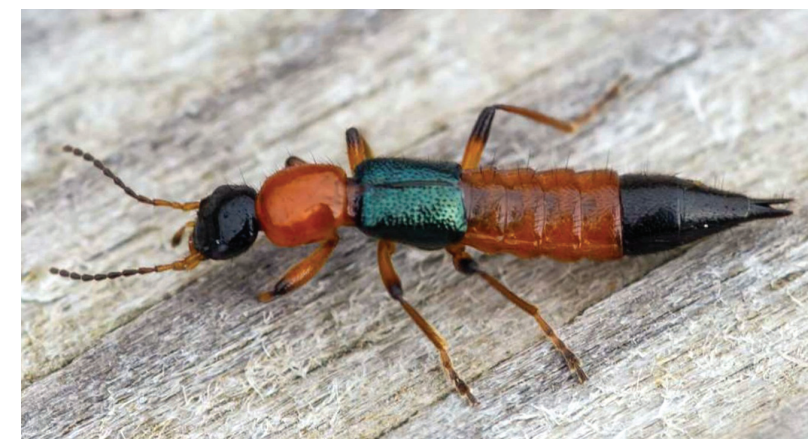

Figure 3. Paederusfuscipes (Order: Coleoptera Family: Staphylinidae Genus: Paederus Species: fuscipes) 
Table 1. Differences between experimentally induced skin lesions by cantharidin and by pederin

\begin{tabular}{|c|c|c|}
\hline Feature & Pederin & Cantharidin \\
\hline $\begin{array}{l}\text { Delay between contact and } \\
\text { onset of erythema }\end{array}$ & $36-72 \mathrm{~h}$ & $18-24 \mathrm{~h}$ \\
\hline Character of erythema & Marked and painful & Mild or symptomless \\
\hline Character of vesicle & $\begin{array}{l}\text { Small or very small; clear fluid, becoming } \\
\text { purulent; tendency to coalesce; deep base }\end{array}$ & $\begin{array}{l}\text { Small, rapidly coalescing; clear } \\
\text { fluid on a superficial base }\end{array}$ \\
\hline Symptoms & Pronounced itching and burning & Almost none \\
\hline Healing & Formation of a crust & By resorption or by blister bursting \\
\hline Residual lesion & $\begin{array}{l}\text { Marked persistent pigmentation; } \\
\text { itching may also be present }\end{array}$ & $\begin{array}{l}\text { May be none; may be light } \\
\text { transient pigmentation }\end{array}$ \\
\hline
\end{tabular}

are susceptible to desiccation from excessive heat (9). Life cycle consists of at least two larval instar stages between egg and pupa, before emergence of the adult beetle which usually appears during or around conclusion of the damp season (10). Agricultural workers are most affected during the day since exposure occurs while beetles feed on the crops. At night, beetles are attracted to light and may enter houses. The beetles are attracted more to fluorescent than incandescent sources of light so much so that an outbreak of blistering beetle dermatitis in Tanzania was arrested after mercury tube fluorescent lights were replaced with incandescent bulbs (1). History of contact with the beetle may not always be available as exposure to the toxin may occur while asleep. The exposed parts of the body like face, neck, upper and lower extremities are most often affected. It is interesting to note that it is not the beetle, but Pseudomonas-an endosymbiotic gram-negative bacteria which synthesizes the toxin instead (11). Female beetles are believed to be the carriers of the endosymbiont bacteria. The larvae-forms acquire it by ingestion of eggshells contaminated with Pseudomonas (12). Although pederin constitutes approximately $1 \%$ of the body weight of the beetle, it is an extremely potent toxin which completely inhibits cell growth at concentrations as low as 1.5 nanograms per mililitre and has median lethal dose $\left(\mathrm{LD}_{50}\right)$ of 2 milligram per kilogram for humans $(13,14)$. At molecular level, pederin induces an apoptotic reaction by inhibiting mitosis and thereby disrupting DNA and protein synthesis which correlates clinically with an acute necrotic reaction (13). Since blister beetles neither sting nor bite, allowing them to roam over the skin does not cause any reaction. However, crushing them against the skin leads to secretion of pederin or cantharidin present in hemolymph which leads to blistering. Apart from causing dermatitis, cantharidin has been used in the treatment of warts and molluscum (15). Pharmaceutical grades of cantharidin available in some countries are: Cantharone and Canthracur PS (0.7\% in collodion base); Canthacur PS (1\% cantharidin, 30\% salicylic acid, 5\% podophyllin); and cantharidin crystals with collodion base sold separately (16). Also of interest is oral ingestion of blistering beetles as aphrodisiac and abortifacient but is associated with serious adverse effects like gastrointestinal hemorrhage, hemorrhagic shock, renal and cardiac toxicity and death (17-19). Skin manifestations of contact exposure to toxin presents classically with sudden onset of painful linear erythematous plaques studded with vesicles sometimes coalescing to form bullae which heal with post inflammatory hyperpigmentation over 10-14 days (3). Another classical presentation is "kissing lesions" on the contiguous areas of the skin in close physical contact with each other e.g. axillary area and cubital and popliteal fossae which underlines the fact that smearing of the vesicant fluids to the contiguous surfaces lead to the appearance and spread of the lesions (20). Our case showed classical kissing lesions on the ipsilateral upper limb which might have been caused due to smearing of the vesicant fluid on the adjacent areas in contact with each other. The lesions around the right eye occurred through contamination of finger tips of left hand while attempting to dislodge the beetle crawling on the right forearm. Involvement of eye and periocular area oc- 
curs due to contamination by toxin and has been termed as "Nairobi eye" $(21,22)$. Early lesions show spongiosis comprising of neutrophils, exocytosis, scattered acantholysis and even necrosis (23). Blistering beetle dermatitis mimics different dermatoses like herpes simplex and herpes zoster, impetigo contagiosa, Toxicodendron dermatitis, phytophotodermatitis, millipede dermatitis, liquid burns, dermatitis artefacta and in case of periorbital involvement periorbital cellulitis (24). Treatment consists of washing of the affected area and application of mild topical steroid cream (25).

\section{Conclusion}

Blistering beetle dermatitis classically affects the exposed areas of the body. Our case too presented with lesions on the exposed parts - the right periocular area and right antecubital fossa. This presentation although theoretically classical, may be misdiagnosed as herpes zoster ophthalmicus as pain and burning sensation is the predominant complaint in both the clinical scenarios. However sudden onset of lesions overnight or in hours without a significant prodrome as seen in herpes zoster and presence of "kissing lesions" in some cases further support the diagnosis as blistering beetle dermatitis. Detailed history and clinical examination is essential to diagnose this condition.

\section{Abbreviations}

$\begin{array}{ll}\text { DNA } & \text { - Deoxyribonucleic acid } \\ \text { PS } & \text { - Pharmaceutical Services }\end{array}$

\section{References}

1. Narasimhalu CR, Murali A, Kannan R, Srinivasan N. Blister beetle dermatitis. J Indian Med Assoc. 2010;108(11):781-2.

2. Verma CR, Agarwal S. Blistering beetle dermatitis: an outbreak. Med J Armed Forces India. 2006;62(1):42-4.

3. Cressey BD, Paniz-Mondolfi AE, Rodríguez-Morales AJ, Ayala JM, De Ascenção Da Silva AA. Dermatitis linearis: vesicating dermatosis caused by paederus species (coleoptera: staphylinidae). Case series and review. Wilderness Environ Med. 2013;24(2):124-31.

4. Karthikeyan K, Kumar A. Paederus dermatitis. Indian J Dermatol Venereol Leprol. 2017;83(4):424-31.

5. Dieterle R, Faulde M, Erkens K. Blister beetle dermatitis: dermatitis linearis. Hautarzt. 2015;66(5):370-3.

6. Singh G, Yousuf Ali S. Paederus dermatitis. Indian J Dermatol Venereol Leprol. 2007;73(1):13-5.
7. Haddad Junior V. "Sign of the kiss" in dermatitis caused by vesicant beetles ("potós" or Paederus sp.). An Bras Dermatol. 2014;89(6):996-7.

8. Borroni G, Brazzelli V, Rosso R, Pavan M. Paederus fuscipes dermatitis. A histopathological study. Am J Dermatopathol. 1991;13(5):467-74.

9. Wijerathne BTB. Blister mystery. Wilderness Environ Med. 2017;28(3):271-2.

10. Srihari S, Kombettu AP, Rudrappa KG, Betkerur J. Paederus dermatitis: a case series. Indian Dermatol Online J. 2017; 8(5):361-4.

11. Piel J, Höfer I, Hui D. Evidence for a symbiosis island involved in horizontal acquisition of pederin biosynthetic capabilities by the bacterial symbiont of Paederus fuscipes beetles. J Bacteriol. 2004;186(5):1280-6.

12. Kellner RL, Dettner K. Differential efficacy of toxic pederin in deterring potential arthropod predators of Paederus (Coleoptera: Staphylinidae) offspring. Oecologia. 1996; 107(3):293-300.

13. Brega A, Falaschi A, De Carli L, Pavan M. Studies on the mechanism of action of pederine. J Cell Biol. 1968;36(3): 485-96.

14. Morgan ED, Wilson ID. Insect hormones and insect chemical ecology. In: Barton SD, Nakanishi K, Meth-Cohn O, editors. Comprehensive natural products chemistry. Amsterdam; New York: Elsevier; 1999. p. 263-375.

15. Vakharia PP, Chopra R, Silverberg NB, Silverberg Jl. Efficacy and safety of topical cantharidin treatment for molluscum contagiosum and warts: a systematic review. Am J Clin Dermatol. 2018;19(6):791-803.

16. Mathes EF, Frieden IJ. Treatment of molluscum contagiosum with cantharidin: a practical approach. Pediatr Ann. 2010;39(3):124-8.

17. Sandroni P. Aphrodisiacs past and present: a historical review. Clin Auton Res. 2001;11(5):303-7.

18. Diaz P, Carneiro A, Montes V, Alves S. A potentially fatal aphrodisiac: cantharidin poisoning. Acta Med Port. 2020; 33(4):284-7.

19. Cheng KC, Lee HM, Shum SF, Yip CP. A fatality due to the use of cantharides from Mylabris phalerata as an abortifacient. Med Sci Law. 1990;30(4):336-40.

20. Haddad V Jr. "Sign of the kiss" in dermatitis caused by vesicant beetles ("potós" or Paederus sp.). An Bras Dermatol. 2014;89(6):996-7.

21. Poole TR. Blister beetle periorbital dermatitis and keratoconjunctivitis in Tanzania. Eye (Lond). 1998;12(Pt 5):883-5.

22. Mbonile L. Understanding of acute hemorrhagic conjunctivitis (AHC) epidemics and outbreaks of Paederus spp keratoconjuctivitis, periorbital oedema ("Nairobi red eyes") and dermatitis. East Afr J Public Health. 2010;7(3):242-5.

23. Borroni G, Brazzelli V, Rosso R, Pavan M. Paederus fuscipes dermatitis. A histopathological study. Am J Dermatopathol. 1991;13(5):467-74.

24. Hegde SS, Bhat MR. An outbreak of blister beetle dermatitis in a residential school: a clinical profile. Muller Journal of Medical Sciences Research. 2017;8(1):47-51.

25. De Luca DA, Maianski Z, Averbukh M. Paederus dermatitis outbreak in Luanda City, Angola. J Eur Acad Dermatol Venereol. 2018;32(1):e17-8. 


\section{Bulozni dermatitis izazvanih ubodom insekata koji liči na herpes zoster oftalmikus - prikaz slučaja}

\section{Sažetak}

Bulozni dermatitis nastao ubodom insekata su važno dermatološko oboljenje u tropskim zemljama. lako su kliničke karakteristike klasične, nedovoljna svest o ovoj bolesti može izazvati teškoće u dijagnostikovanju. Pored toga, ova vrsta dermatitisa može ponekad da liči na druga oboljenja, što može dovesti do neblagovremenog tretmana i tako produžiti patnju pacijenta. Ovo je prikaz slučaja dermatitisa u obliku plikova izazvanih ubodom insekta koji je prvobitno pogrešno dijagnostikovan kao herpes zoster oftalmikus. Slučaj prezentujemo da bismo podigli svest o ovom dermatološkom oboljenju i prodiskutovali njegovu atipičnu manifestaciju i lečenje.

Ključne reči: Ujedi i ubodi insekata; Kontaktni dermatitis; Koleoptere; Plik; Očni herpes zoster; Dijagnoza; Dijagnostičke greške

Received 2.08.2020.

Accepted 28.12.2020. 